九州大学学術情報リポジトリ

Kyushu University Institutional Repository

\title{
Antagonistic Action of Bacillus sp. AB89 to Phloeospora maculans, Causal Agent of Mulberry Leaf Spot
}

Kim, Kyung-Hee

Laboratory of Plant Pathology, Faculty of Agriculture, Kyushu University

\section{Inoue, Shino}

Fukuoka Agricultural Extension Center

Kawanami, Masakazu

Nissan Chemical Industries, Ltd.

Furuya, Naruto

Laboratory of Plant Pathology, Faculty of Agriculture, Kyushu University

他

https://doi.org/10.5109/24278

出版情報：九州大学大学院農学研究院紀要. 43 (3/4)，pp.337-342，1999-02. Kyushu University バージョン：

権利関係 : 


\title{
Antagonistic Action of Bacillus sp. AB89 to Phloeospora maculans, Causal Agent of Mulberry Leaf Spot
}

\author{
Kyung-Hee Kim, Shino Inoue ${ }^{* 1}$, Masakazu Kawanami ${ }^{* 2}$, \\ Naruto Furuya and Nobuaki Matsuyama \\ Laboratory of Plant. Pathology, Faculty of Agriculture, \\ Kyushu University, Fukuoka 8128581 , Japan \\ (Received October 28, 1998 and accepted November 6, 1998)
}

\begin{abstract}
The control of mulberry leaf spot caused by the infection of Phloesspora maculans (Seplogloeum mori) has been important for sericulture in (ioto islands. Since the chemical control of this leaf-spot disease was not available except for off-season, the possibility of other kint of control measure was tested. Phylloplane bacterium Bacillus sp. AB89 from a rice leaf was quite useful as an antagonist. Culture filtrate of the antagonistic bacterium inhibited spore germination and mycelial growth of leaf spot pathogen. Furthermore, the culture filtratc and living bacterial cells limited distinctly the development of lesions on mulberry leaves in vivo.
\end{abstract}

\section{INTRODUCTION}

Mulberry leaf spot by the infection of Phloeospora maculans was epidemic in China $(1954,1973 \sim 1978)$. In Japan this disease has heen endemic and giving severe damage in Goto islands (Nagasaki prefecture) where sericulture is an important industry (Negi et al., 1992; Baba el al., 1995).

The use of agricultural chemicals, though they are effective to a causal pathogen, has been limited by the anxiety of effects on silkworm growth. Thercfore the application of an antagonistic microorganism was intended. One of the authors, Matsuyama, isolated a phylloplane bacterium from a leaf of rice and named as AB89. This isolate showed wide antagonistic spectra to various phytopathogenic fungi and bacteria and was identified as Bacillus species based on the experimental results for numerous key characteristics in physiological, biochemical and serological tests (Inoue et al., 1993). The authors estimated the ability of the isolate Bacillus sp. AB89 as a novel control measure against mulberry leaf spot disease. The results will be contributed in the present report.

\section{MATERIALS AND METHODS}

\section{Plant used}

Mulberry (Morus alba L. cv. Minamisakari) was raised in potted soil (Clay pot: $26.5 \mathrm{~cm}$ in inner diameter and $22 \mathrm{~cm}$ in depth) fertilized with the granulous compound fertilizer for mulberry tree (Toku-No. 10) in the green house.

\footnotetext{
* Fukuoka Agricultural Extension Center, Fukuoka, Japan.

*2 Nissan Chemical Industries, Ltd., Shiraoka, Japan.
} 


\section{Culture of inoculum}

Phloespora maculans (Bereng.) Allescher (Septogloeum mori Briosi et Cavara), the causal agent of the mulberry leaf spot was cultured on PSA medium [potato decoction (200 g) $1 \mathrm{l}$, sucrose $15.0 \mathrm{~g}$, agar $15.0 \mathrm{~g}$. Spores were obtained from the surface of PSA plates after culture for $10 \sim 15$ days at $25^{\circ} \mathrm{C}$.

\section{Culture of antagonistic bacterium}

Bacillus sp. AB89 was shake-cultured $(125 \mathrm{rpm})$ in potato semi-synthetic medium [PS medium: potato decoction (300 g) $1 l, \mathrm{Na}_{2} \mathrm{HPO}_{4} \cdot 12 \mathrm{H}_{2} \mathrm{O} 2 \mathrm{~g}, \mathrm{Ca}\left(\mathrm{NO}_{3}\right)_{2} \cdot 4 \mathrm{H}_{2} \mathrm{O} 0.5 \mathrm{~g}$; Peptone $5.0 \mathrm{~g}$, Sucrose $15.0 \mathrm{~g}$ ] at $30^{\circ} \mathrm{C}$ for $72 \mathrm{hrs}$. The cultured fluid was centrifuged at $7,500 \times \mathrm{g}$ for $20 \mathrm{~min}$. Bacterial pellet was washed twice with distilled water, adjusted to the concentration of $11 \sim 13 \times 10^{8} \mathrm{cfu} / \mathrm{ml}$ and used for antagonist pretreatment. Supernatant after centrifugation was also used as a fluid of crude antibiotics.

\section{Tests of antagonistic activity of Bacillus sp. AB89 in vitro}

The culture filtrate was diluted 2, 4, 10 times with distilled water, membrane-filtered and tested for antifungal activity to germination of spores on glass slides in Petri-dish of RH $100 \%$ and mycelial growth of $P$. maculans by penicillin-cup method.

\section{Evaluation of antagonist}

Bacterial cells and culture filtrate of Bacillus sp. AB89 were sprayed on the leaves of potted mulberry trees and dried, respectively. Then the spore suspension $(11 \sim 27 \times$ $10^{\circ} \mathrm{cfu} / \mathrm{mu}$ ) of the pathogen of leaf spot, $P$. maculans was sprayed and inoculated trees were incubated at $25^{\circ} \mathrm{C}$ for $24 \mathrm{hrs}$. Distilled water and not cultured fresh PS fluid were sprayed as the check.

Fifteen days after inoculation, the number of lesions formed on the 4 th leaf from the uppermost leaf was counted and expressed as lesions $/ \mathrm{cm}^{2}$. The leaf area was calculated by the automatic leaf-area meter (Hayashi denko Co.).

\section{RESULTS AND DISCUSSION}

The biological control with antagonistic Bacillus spp. has been well documented and some of the antagonists have been practically used for control of various foliate diseases (Fravel et al., 1977; Baker et al., 1983, 1985; Spurr et al., 1985; Rytter et al., 1989). The practical use of living cells of Bacillus sp. AB89 and antibiotic (s) which will be involved in the antagonism for control of the mulberry leaf spot disease was intended.

The antifungal activity of culture filtrate of Bacillus sp. AB89 against $P$. maculans, was presented in Table 1. Germination of spores from the lesions of diseased mulberry leaves and PSA medium was heavily inhibited. Rarely a few spores germinated but their growth was abnormal and ceased their elongation. As can be seen in Fig. 1, morphological abnormality such as swelling and granulation of the treated spore cells were observed.

The mycelial growth was also inhibited even when the culture filtrate was diluted 10 times. The hyphae of the surrounding region of the inhibition zone were morphologically abnormal and protrusion or swelling of hyphal cells was observed (Fig. 2). Such 
Table 1. Inhibition of spore germination of Phloespora maculans by culture filtrate of Bacillus sp. AB89 at various concentrations.

\begin{tabular}{|c|c|c|c|c|c|}
\hline \multicolumn{4}{|c|}{ Concentration of culture filtrate } & \multirow{2}{*}{$\begin{array}{c}\text { Distilled } \\
\text { Water }\end{array}$} & \multirow{2}{*}{ Conidia from } \\
\hline Original & $1 / 2$ & $1 / 4$ & $1 / 10$ & & \\
\hline $0.00^{1 ;}$ & 0.00 & 0.00 & 0.00 & $88.6 \%$ & diseased leaves \\
\hline 0.00 & 0.01 & 0.01 & 0.01 & 76.6 & PSA miedjurn \\
\hline
\end{tabular}

1): Germination was counted at 24 th hr.
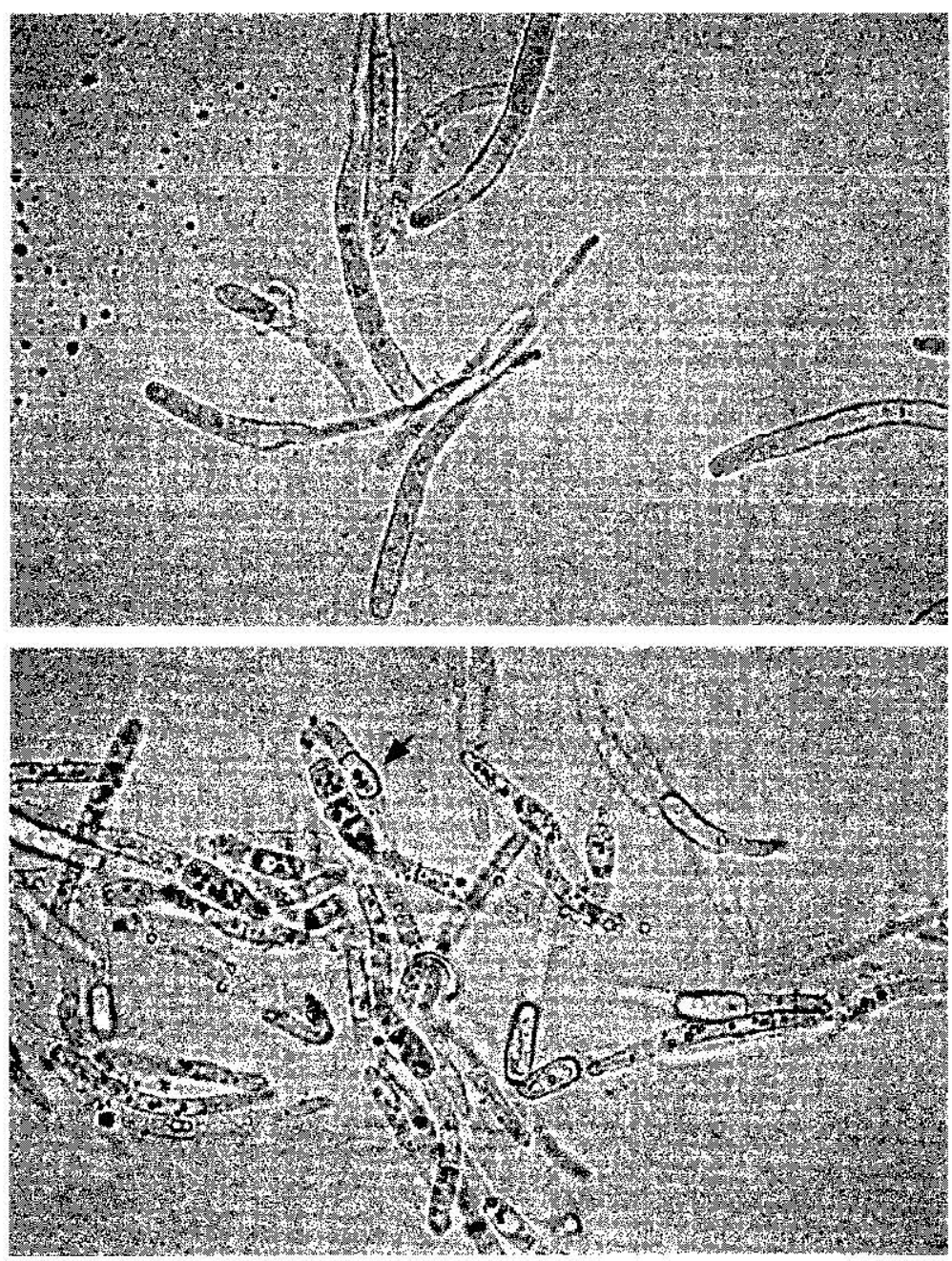

Fig. 1. Effect of antifungal substance (s) of Bacillas sp. AB89 on germination of $P$. maculans (Upper: Check, Lower: Treated with culture filtrate; Swelled and granulated cells) 


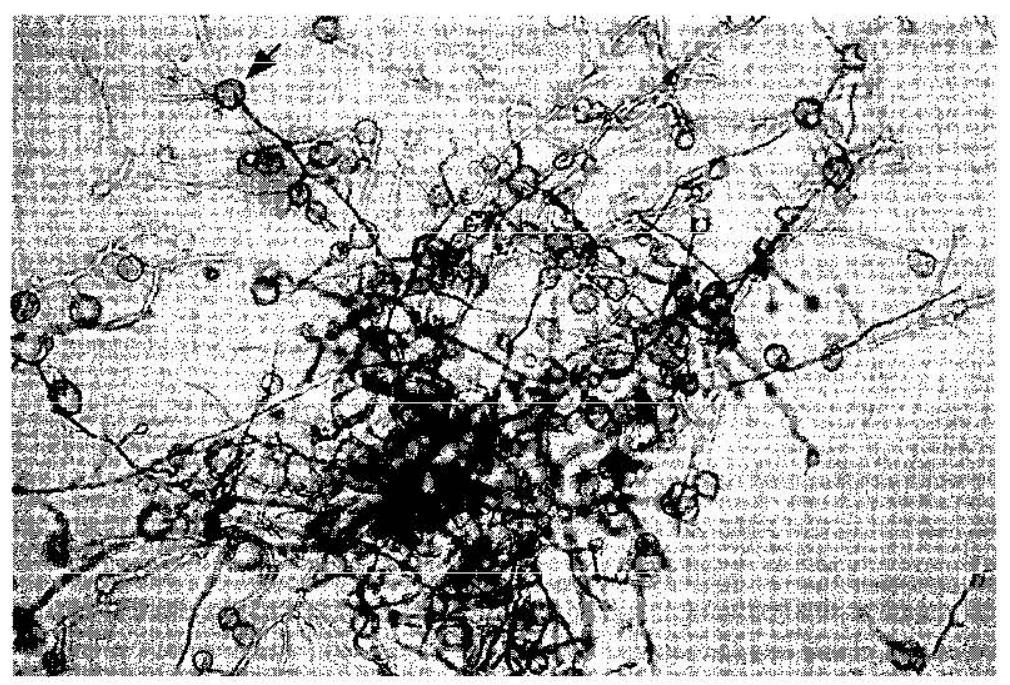

Fig. 2. Swelled hyphae of $P$. maculans at inhibition zone on the PSA plate

Table 2. Suppression of leaf-spot development by culture filtrate and bacterial cells of Bacillus sp. AB89.

\begin{tabular}{c|ccccc}
\hline Trial & \multicolumn{4}{|c}{ Treated with ${ }^{1)}$} & $\begin{array}{c}\text { Concentration of pathogen } \\
\text { (P. maculans; cfu/m) }\end{array}$ \\
\cline { 2 - 5 } 1 & CF & BC & Check 1 & Check 2 & $13 \times 10^{3}$ \\
2 & $0.00^{2} \mathrm{~b}^{3}$, & $0.13 \mathrm{~b}$ & $0.39 \mathrm{ab}$ & $0.78 \mathrm{a}$ & $11 \times 10^{3}$ \\
3 & $0.00 \mathrm{~b}$ & $0.02 \mathrm{~b}$ & $0.39 \mathrm{a}$ & $0.49 \mathrm{a}$ & $27 \times 10^{4}$ \\
\hline Mean & $0.00 \mathrm{~b}$ & $0.12 \mathrm{~b}$ & $1.45 \mathrm{a}$ & $1.24 \mathrm{a}$ & - \\
\hline
\end{tabular}

1) CF: Culture filtrate BC: Bacterial cells Check 1: Distilled water Check 2: Potato semi-synthetic medium

2) Number of lesions $/ \mathrm{cm}^{3}$ leaf area

3) Numbers followed by different letters differ significantly at $P=0.05$ level in I uncan's multiple range test.

phenomenon was sometimes observed at confronting fungus with antagonistic microorganisms and attributed as a result of the inhibition of chitin synthesis in fungal cell-wall (Ohta et al., 1970; Kikutake et al., 1991).

Mulberry leaves were pretreated with the culture filtrate or living cells of Bacillus sp. AB89 and challenge inoculated with $P$. maculans, the causal agent of leaf spot. As shown in Table 2 and Fig. 3, the infection was highly limited by the treatments. One of the authors tested the inhibitory effects of these antagonist and antibiotics on silkworm growth. No negative effects on the growth and behaviors of silkworm were observed (Kawanami el al., 1997). These results will strongly indicate the usefulness of this isolate Bacillus sp. AB89 as a control measure. 

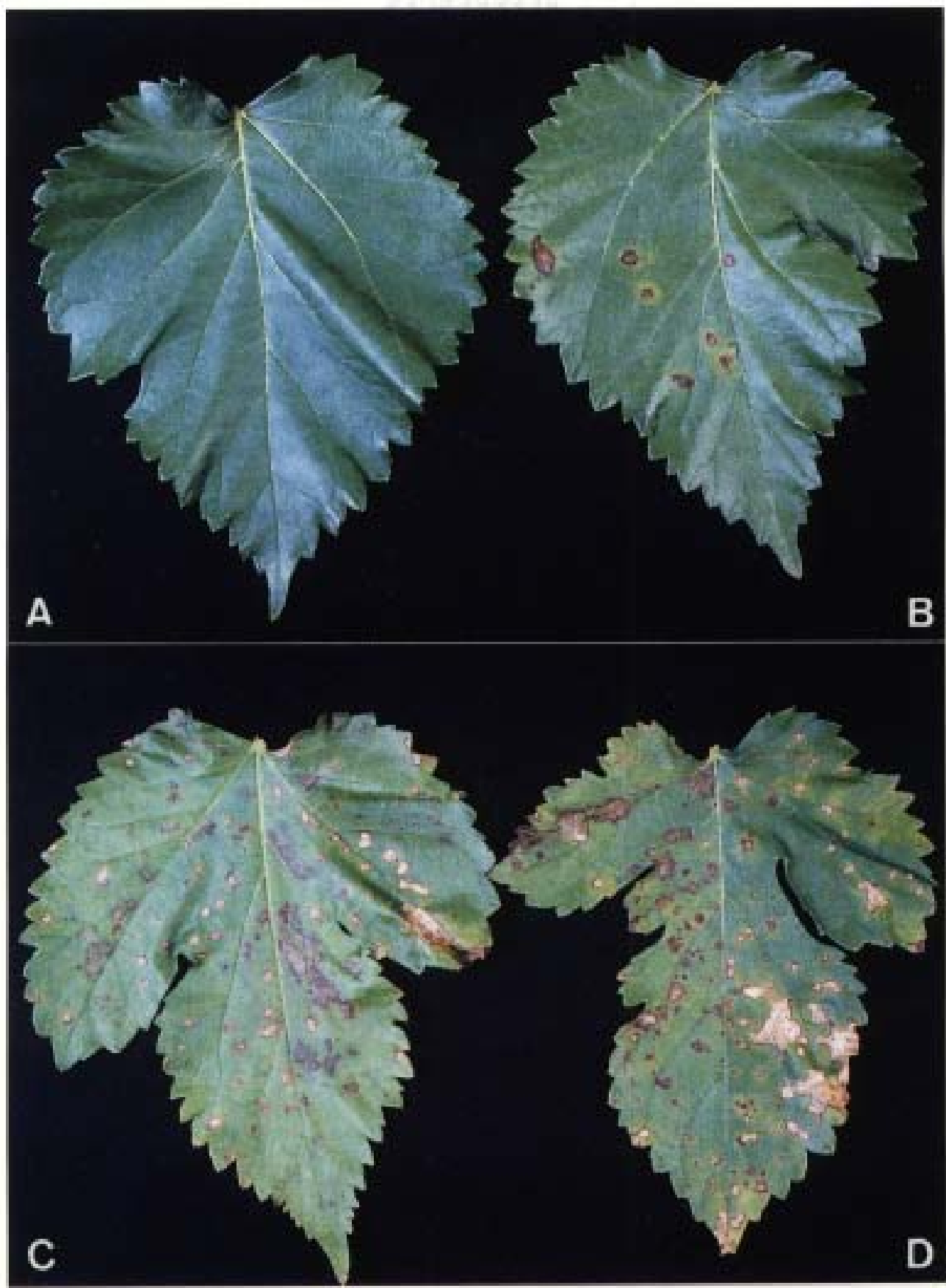

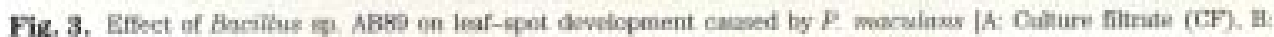
Elacterial cella (BC), C. Distilled water (DW), D: Potate semi-synitwetk median(PS)] 


\section{REFERENCES}

Baba, S., K. Matsuo, W. Negi, Y. Suga, T. Ogawa and M. Murayama 1995 Some ecological studies on leal spot of mulberry. Proc. Assoc. Pl. Prot. Kuzushu, 41: 47-50 (in Japanese)

Baker, C. .J., J. R. Stavely and N. Mock 1985 Biocontrol of bcan rust by Bacillus subtilis under field conditions, Plant Dis, 69:770-772

Baker, C. J., J. R. Stavely, C. A. Thomas, M. Sasscr and J. S. Mactall 1983 Inhibitory effect of Bacillus subtitis on tromyces phaseoli and on development of rust pustules on bean leaves. Phighorathology: 73: 1148-1152

Fravel, D. R. and 11. W. Spurr, It. 1977 Biocontrol of tobacco brown-spot disedse by Bacillus cereus subsp. mucoides in a controlled enviroment. Thatoputhology, 67: 930-932

Inouc, S., K. II. Kim, M. Nishioka, N. Furuya, Y. Takanami and N. Matsuyama 1993 Production of anlibiotic (s) by Bacillus sp. AB89. Proc. Assoc. Pl. Prot. Kyushu, 39: 56-59 (in .Japanese)

Kawanami, M., Y. Banmo, K. H. Kim, S. Yamanoto, N. Furuya and N. Mat.suyatud 1997 On an antibiolic: producing bacterium Borillus subtilis AB89 Il. Antifungal effect, against Phloesospore mactares and characteristies of the antibiolics. Aren. Phytopath. Soc. Jpn., 63: 216 (abstract in Jananese)

Kikutake, K., N. Matsuyama and S. Wakimoto 1991 Antagonistic activity of Xamthomomads against. phytopathogenic fungi and isolation of antifungal substance. Anm. Phytopath. Soc. Jph., 57:61-64

Negi, W., K. lde, T. Ota, N Matsuyama and K. H. Kim 1992 Severc oceurrenee of mulberry leaf spot in Goto, Nagasaki Prefccturc. Proc. Assoc. Hl. Prot. Kyushu, 38: 52-54 (in Japanese)

Ohla, N., K. Kalkiki and T. Mistlo 1970 Studies on the mode of action of Polyxin T) parl. I. Fffect of Polyxin I) on the synthesis o[ fungal cell wall (hilin. Agr. Biol. Chem., 34(8): 1224 1234

Rytter, J. L., F. L. Lukezic, R. Craig, and G. W'. Moorman 1989 Biological control of geranium rust by Bacillus subtilis. Phytopathology, 79: $367-370$

Spurr, H. W. Ir. and C. R. Knudsen 1985 Biological control of leaf diseases with bacteria. "Riological control on the phylloplane." (Winclels, C. E. and S. F. Iindow, eds.): 45-62 